\title{
HÂKIMMLERİN HUKUKÎ SORUMLULUĞUNA ILLISKINN HÜKÜMLERİN (HUMK 573-576), "HÂKİM" KAVRAMI AÇISINDAN UYGULAMA ALANI
}

\author{
Dr. Erdal TERCAN*
}

\section{A. GENEL OLARAK}

Hâkimlerin hukukî sorumluluğunu düzenleyen Hukuk Usâlü Muhakemeleri Kanunu'muz (HUMK), Neuchâtel Usûl Kanunu'ndan iktibas edilmiştir. Ancak, HUMK'nun 10. babında, 573576'ncı maddeler arasında düzenlenen hâkimlerin hukukî sorumluluğuna ilişkin hükümler Neuchâtel Usâl Kanunu'ndan alınmamış̧ır. Bu hükümlerin temelini eski "Usul-â Muhakemat-1 Hukukiye Kanunu"nda 255-270'inci maddeler arasında "iștika-i anilhükkâm" başlığt altında düzenlenmis olan ve Fransız Usûl Kanunu'ndan ahınan "prise á partie" (Art. 505 Code de procèdure civile) (hâkimden şikâyet, hâkimin dâva edilmesi) kurumuna ilişkin hükümler teşkil eder $^{1}$. Bu hükümler de aynen alınmayıp, birtakım değişiklik ye ilâyelerle kabul edilmiştir. Bu nedenle, hâkim aleyhine tazminat dâvaS1 açılabilmesi için Fransız hukukundaki "izin sistemi" bizde hiç düşünülmemiş; bu konuda Fransa'da yapılan 1933 yılındaki değisiklik de hukukumuza yansitılmamıştır. Bunun sonucu olarak, ülkemizde hâkimlerin sorumluluğu ve dolayısıyla Devletin yargısal faaliyetlerden sorumlu tutulup tutulamayacağı konusunda farklı görüşler ortaya çıkmıştır².

* A.Ü. Hukuk Fakültesi Medenî Usual ve Icra-tflâs Hukuku Anabilim Dalı Araştırma Görevlisi.

1. Karafakih, Ismail Hakkı: Hukuk Muhakemeleri Usâlī Esaslan, Ankara 1952, s.36. Fransız hukukundaki anlamıyla "prise à partie", Isviçre'nin sadece Waadt ve Fribourg kantonlarında kabul edilmiştir. Diğer kantonlarda, hâkiṇlerin sorumluluğu için de, memurların sorumluluğuna ilişkin genel hükiłmler geçerlidir. Kaufmann, Otto K.: Die Verantwortlichkeit der Beamten und die Schadenersatzpflicht des Staates in Bund und Kantonen (ZSR 1953, Bd.72, s.245a).

2. Bu konu için bkz. Tercan, Erdal: Hâkimlerin Sorumluluğu, Ankara 1988, s.8 vd. (A.Û. Hukuk Fakiültesi Kütiliphanesi Nr.104004 da kayıtlı yayınlanmamıs yïlssek lisans tezi); Karafakih, Ismail Hakk: Hâkimlerin VerdikJeri Kararlandan Dolayı Şahsen ve Devletin Dolayısıyla Mesuliyetleri (SBFD 1956/3, C. XI, s.40 vd.). 
Hukuk Usûlü Muhakemeleri Kanunu'muz, hâkimlerin hukukî sorumluluğunu kabul eden ve reddeden görüşleri dikkate alarak telifçi bir yol izlemiştir. Buna göre, hâkimler, hukuka aykırı fiillerinden sorumlu tutulmuşlar; ancak, sorumluluk sebepleri sınırsız olarak kabul edilmeyip, m.573' $\mathrm{de}^{3} 7$ bend olarak sınırlandırılmıs ve sorumluluk dâvası da ayrı bir prosedüre tâbi tutulmuştur ${ }^{4}$. HUMK, hâkimlerin sorumlu tutulacakları sebepleri belirlerken, ağır kusur veya kasdı esas almıştır. Yani, 573'üncü maddede sayılan belirli sorumluluk sebepleri, hâkimin kast veya ağır kusurunun bir sonucu olarak ortaya çıkabilecek olan durumlardir ${ }^{5}$. Ayrica, belirlenen bu sorumluluk sebepleri Türk Ceza Kanunu'na göre de suç teşkil etmektedir (m.573/1-TCK m.244; 573/3,4-TCK m.339, 349; m.573/ 5-TCK m.214, 217; m.573/6-TCK m.231).

HUMK m.573, hâkimlerin hukukî sorumluluğuna ilişkin hükümlerin uygulama alanını "hâkim ve icra reisi ${ }^{6}$ aleyhine aşăğda yazllan sebeplere binaen tazminat dâvası ikame olunabilir" ifadesiyle belirlemiş bulunmaktadır. Sözkonusu maddeye göre, sorumluluğa ilişkin özel hükümler, sadece hâkimler hakkında uygulanabilecektir. Hâkimlerin, görevlerini tarafsızlık ve bağımsızlık içinde yerine getirebilmeleri amacıyla kabul edilen, bu özel hükümlerden kimlerin yararlanacağını, bir başka ifadeyle 573'üncü maddede geçen "hâkim" kavramına kimlerin dahil olduğunu belirlemek gerekir. Acaba m.573'de geçen "hâkim ve icra reisi" ifadesine sadece

3. Aynca kanun ismi verilmeden kullanılan "m." kusaltmaları Hukuk Usûlü Muhakemeleri Kanunu'na aittir.

4. HUMK m.573-576 hükümleri "hâkimin vicdanî kanaatindeki bağımsızlığın, yargı erkinin herhangi bir etki altunda kalmamasım ve adalete gliven duygusunun sarsilmamasını temin amacıyla yasaya konulmuştur. Gerçekten hâkimlerin hukukî sorumlulukları nedenine dayanan dâvalar özel usûl ve muieyyidelere bağlanmadığı takdirde ilgililerce kötliye kullanılarak bâkim hakkunda red sebepleri ihdas edilmesi kolaylaşacak, mahkemelerin gereği gibi çalışmasına ve adaletin selâmetle dağıtılmasına halel gelebilecektir. Bu itibarta söz konusu özel hükümler hem meydana gelecek zararlı durumu düzeltip tamir etmek hem de haksız dâvalan önlemek amacıyla kabul edilmişsir." HGK 14.11.1970, Iff. 185/623 (İBD 1971/3-4 s.308-309).

5. Üstchndağ, Saim: Medenî Yargılama Hukuku, C.I, II, 5 B., Istanbul 1992, s. 107; Postacıoğlu, than E.: Medenî Usul Hukuku Dersleri, 6.B., Istanbul 1975, s.67.

6. Icra ve Îfâs Kanununun Bazı Maddelerinde Deģj̧̧iklik Yapılmasına Dair Kanun Tasarssı'nda (m.2) "icra reisliği" kurumu kaldınimaktadır. Bu konuya ilişkin olarak genel gerekçede "bugünkï uygulamada var olan icra reisliği kurumundan vazgeçilerek, icra müdürlüklerinin bağlı olduklan icra tetkik mercii hâkimlerinin gözetim ve denetimi altında tutulmalan öngörülmüş̧, icra hâkimlerinin icra müdürlüklerinde çalışan personel üzerindeki etkinlikleri arturlarak, icra işlemlerine karşı yapılan itiraz ve şikâyetlerin azaltılması amaçlanmışıı" denilmektedir. (İcra ve Iflâs Kanunu'nun Bazı Maddelerinde Değişiklik Yapılmasına Dair Kanun Tasarısı ve Adalet Komisyonu Raporu Genel Gerekçesi). 
575, I'de belirtilen ilk derece hâkimleri mi dahildir; yoksa, yüksek yargı organlarında görev yapan hâkimler de buraya dahil midir?

\section{B- ILK DERECE HÂKIMLERİ}

Hukukumuzda, hâkimlerin hukukî sorumluluğuna ilişkin hükümler, (m.573-576) genel ve özel bütün hukuk mahkemelerinde görev yapan hâkimler (ticaret mahkemesi, iş mahkemesi, kadastro mahkemesi vb. hâkimleri), icra tetkik, mercii hâkimleri ${ }^{7}$, idari yarg1 hâkimleri (2802 s. Hâkimler ve Savcılar K.m.3/a-2) ${ }^{8}$ hakkında uygulanır. Kanunkoyucu, hakimin görevini tarafsızlık ve iç huzuru ile yerine getirebilmesi için, onun sorumluluğunu özel bir şekilde düzenlediğinden, ismi ne olursa olsun, doğrudan doğruya sürekli veya geçici olarak yargısal bir görev yapan her kişi hakkında bu özel hükümlerin uygulanması gereklidir?

Yargıtay, bir içtihadı birleştirme karan ile ${ }^{10}$ Ceza Muhakemeleri Usulüi Kanunu'nda, ceza hâkimlerinin sorumluluğu hakkında hiçbir hüküm mevcut olmadığından, onlar hakkında da HUMK'nun ilgili hükümlerinin uygulanacağını belirtmiştir.

Askerî mahkemelerde görev yapan hâkimler de HUMK'nun sözkonusu hükümlerine göre sorumlu tutulabilirler ${ }^{11}$.

Fransız içtihatları da "hâkim" kavramına yargısal görevi olan herkesi dahil etmektedir. Fransa'da idare memuru olduklan halde,

7. Anayasa Mahkemesi bir kararunda (26.10.1965, 25/57, RG 8.12.1965; sayı 12171) icra tetkik mercii görevini yapanların hâkim sıfatı taşıdıklannı ve icra tetkik menciinin de mahkeme olarak kabul edilmesi gerektiğini belirtmiştir. Bu nedenle, icra tetkik mercileri de Anayasa Mahkemesine başvurabilirler (aym yơnde Anayasa Mahkemesi'nin 8.10.1974, 17/41 sayslı karan, RG 29.1.1975, say1 15133). Icra tetkik mercii hâkimleri dışında kałan icra müidürú, yardımcılar, müstahdemler vb. görevlilerin sorumlulukları buraya dahil değildir. Zira, HUMK m.573 sadece "icra reisi"nden sözzetmektedir.

8. Kuru, Baki: Hukuk Muhakemeleri Usûlü, C.IV, 5.B., Ankara 1991, s.3942 (Kuru IV); Ustỉndağ, s.108; Hallaç, Ali: Yargıçların Hukuksal Sorumluluğu (Mersin Bar. Der. 1987/3, s.58); Doğanay, İsmail: Yargıtay Başkan ve Üyeleri Aleyhine Doğndan Doğruya (Hukukî Sorumluluk) Davası Açılmaz mı? Prof. Dr. Ernst E. Hirsch'e Armağan, Ankara 1986, s.672; "HUMK m.573'de geçen "hâkim" tâbiri ile kaza hakkı kullanan kimseler kastedilmiştir. Bu tâbir yalnız adliye mahkemeleri hâkimlerine milinhasur bulunmamaktadur." 4. HD 29.1.1959, $1386 / 963$ (Son İçt. 1959/134, s.3899); farkl görtiş için bkz. Postacioğju, s.74.

9. Belgesay, Emcet: Tưrk Hukuku'nda Hâkimin Hukukô Mesuliyeti, Istanbuł 1956, s.54 (E. Belgesay).

10. 25.3.1931, 19/25 sayll IBK (RG 3.5.1931, S.1786).

11. Kuru IV s.3942; 4.HD 29.1.1959, 1386/963 (Son Içt. 1959/134, s.3899-3901). 
yargısal alana ilişkin bazı faaliyetlerde bulunan polis komiserleri, kır bekçileri vs.'de özel sorumluluk rejiminden yararlanabilmekte$\operatorname{dir}^{12}$.

Alman hukukunda, meslekten hâkimler (dâva hâkimi, sicil hâkimi, vesâyet hâkimi) gibi, meslekten olmayan hâkimler de, örneğin fahrî mahkeme üyeleri, jüri üyeleri ve mahkemenin diğer adlî görevlileri de özel sorumluluk rejiminden (BGB $§ 839$, II) yararlanmaktadır ${ }^{13}$. Fakat, yargılama sırasında tutanağın yazılmasında hâkime yardım eden ve bir irade beyan etmeyen memurların sorumluluğu bu özel rejime tâbi değildir ${ }^{14}$.

HUMK, hâkimler için öngörülen hükümlerin, hakemler için de hangi hallerde uygulanabileceğini belirtmektedir. Örneğin, m.521'de hâkimlerin reddine ilişkin hükümlerin hakemler için de uygulanabileceği belirtilmektedir. Acaba m.573-57.6'da öngörülen özẹl sorumluluk rejimi hakemler için de uygulanabilir mi?

HUMK'da, bu konuya ilişkin olarak herhangi bir düzenleme yoktur. Ĕger, hakemlerin de hâkimler gibi özel sorumluluk rejimine tâbi tutulmalan istenseydi, bu konuda da hâkimlerin hukukî sorumluluğuna ilişkin hükümlere atıf yapılırdı. Oysa, bu hïkümlerin hakemler için de geçerli olacağına ilişkin hiçbir işaret mevcut değil$\operatorname{dir}^{15}$. Aynca, hakem sözleşmesi, hakeme başviran taraflarla hakem veya hakemler arasında kurulan ve belli bir hukukî uyuşmazlığa ilişkin, tamamen borçlar hukukuna tâbi bir sözleşmedir. Oysa, hâkimlerin hukukî sorumluluklarının özel bir düzenlemeye tâbi tutulmasının sebebi, hergün kendilerine arzedilen çok sayıda dâvada hatâsız iş görmelerinin zorluğu ve değerli hukukçuların, sorumluluk korkusu ile bu görevi kabulden kaçınmalarını önlemektir. Hakemler için bu sakıncalar sözkonusu olmayacağından, onların sorumluluklarını m.573-576'ya değil, genel hükümlere tâbi tutmak gerekir $^{16}$.

12. Tribunal CiV, Laudun 28 Ocak 1949 D. 1949 SOM., s.27 (E. Belgesay s.54'den naklen).

13. Erman, Walter: Handkommentar zum bürgerlichen Gesetzbuch, 4. Aufl. München 1967 , s.2006 vd.

14. Jaenicke, Günter: Laenderbericht Bundesrepublik Deutschland, in Haftung des Staates für rechtswidriges Verhalten seiner Organe, Köln-Berlin 1967, s.128.

15. Belbez, Hikmet: Hakemlerin Mesuliyetleri (AÛHFD 1959/3-4 s.353-358).

16. Bilge, Necip: Meden̂́ Yargılama Hukuku, 2.B., Ankara 1967, s.88-89; Kılıçoğlu, Ahmet: Hâkimlerin Hukukî Sorumluluğu (AÜHFD 1973/1-4, s.241; Hallaç s.58; Belbez s.358; E. Belgesay s.56; farklı gönüşte Kuru IV s.4028. 
Mecburî tahkim ile ilgili $3533 \mathrm{~s}$. Kanuna göre hakem sıfatıyla hareket eden hâkimler aleyhine m.573-576 hükümlerine göre tazminat dâvası açılabilir ${ }^{17}$. Zira, $3533 \mathrm{~s}$. Mecburî Tahkim Kanunu'nun 4'üneü maddesinde belirtilen kamu kuruluşları arasında çıkan uyuşmazlıklar, o yerde bulunan en yüksek dereceli hukuk (asliye hukuk veya ticaret mahkemesi) hâkimi tarafından, mecburî hakem sıfatıyla çözümlenir. Burada hâkim, hakem sıfatını ihtiyarî tahkimde olduğu gibi uyuşmazlığın tarafları arasında yapılan ve borçlar hukukuna tâbi olan bir tahkim sözleşmesinden almamakta, bu sıfat hâkime, kanun tarafından verilmektedir. Uyuşmazlığın çıktığı yerdeki yüksek dereceli hâkimin bu görevi kabul edip etmemekte bir seçim hakkı yoktur. Bu niteliğiyle de mecburî hakem, hâkimlerle paralellik göstermektedir. HUMK m.573-576 hükümlerinin mecburî hakemler hakkında da uygulanması bu nedenle kabul edilmelidir ${ }^{18}$.

HUMK m.573-576 hükümleri, hâkimlerin, ancak yargısal faaliyetleri hakkında uygulanabilir. Yargısal nitelik taşımayan, idarî faaliyetleri sırasında vermiş oldukları zararlar için de bu hükümler uygulanamaz ${ }^{19}$. Hâkimlerin mahkeme kalemindeki işlemlerin yiirütülmesi ve personelin idaresi gibi idarî faaliyetleri sırasında vermiş oldukları zararlar için hizmet kusuruna dayanarak Adalet Bakanlığı'na karşı idare mahkemesinde bir tam yargı dâvası açılabilir ${ }^{20}$. Ortaya çıkan zarar, hâkimin şahsî kusuruna dayanmakta ise, haksız fiil hükümlerine (BK m.41 vd.) göre hukuk mahkemelerinde tazminat dâvası açmak mümkündür ${ }^{21}$.

Hâkimlik ve savcılık iki ayri meslektir (Anayasa m.140/1). Hâkimlerin görevi yargılama olduğu halde, savcılarınki iddiadır ${ }^{22}$.

17. Kuru IV s.3942; Kılı̧̧̣oğlu s.241; Bilge s.88; HGK 23.5.1951, 4-186/49 (Karaok, Hasan: Hukuk Usî]1 Muhakemeleri Kanunu, Buna Ait İçtihatlar, 2.B., 1957, s.868869); HGK 15.4.1970, 4/537-196 (RKD 1970/8-10, s.142-144); 4.HD 12.1.1951, 1923/233 (Tat. Yar. Kar. 1951/)29-30, s.787-790).

18. Keza, bu hüküimlerin, niteliğine aykırı düşmedikçe, diğer mecburî tahkim hallerinde de uygulanmast sözkonusu olabilir.

19. Kuru IV s.3942; Belgesay, M. Reșit: Hukuk Usûlij Muhakemeleri Kanunu Serhi; C.II, Istanbul 1939, s.554-555 (Belgesay-Serh); Berkin, Necmeddin: Medenî Usul Hukuku Esaslan, Istanbul 1969 s.37 (Berkin-Usul); Hallaç s.59; Doğanay s.673 vd; 4. HD 14.11.1957, 6471/6802 (AD 1958/11 +12, s.638-640); 4.HD 29.1.1959, 1386) 963 (Son tçt. $1959 / 134$, s.3899-3901).

20. Kuru IV s.3942

21. Kuru IV s.3942; Üstündağ s. 107-108.

22. Bu göreviere "adlî görev" demek de mümkündür (Kunter, Nunullah: Muhakeme Hukuku Dah Olarak Ceza Muhakemesi Hukuku, 9.B., Istanbul 1989, s.426). Savculik hakkında geniş bilgi için bkz. Keyman, Selâhattin: Ceza Muhakemesinde Savcıllk, Ankara 1970; Yılmaz, Ejder: Savcılann Hukuk Dâvalarındaki Görevleri (AÜHFD 1972/1-2, C.XXIX, s.255-287). 
Bu iki görevin, savunmayla birleşip yargılama adlı ortak faaliyeti meydana getirmesi, iddia ile yargılama görevinin aynı olduğu anlamına gelmez. Hâkimlerin faaliyeti yargısal olduğu halde, savcllarınki idarî bir nitelik taşımaktadır ${ }^{23}$. Zira, savcının yaptığı iddia görevi, yasama ve yargiya dahil olmayıp, idareye (yüruitmeye) ilişkindir ${ }^{24}$. Savcı bu görevi toplum adına yapmaktadır ${ }^{25}$. Bu nedenle, savcılara karşı, görevlerini yerine getirirken vermiş oldukları zararlardan dolayı, yargılama görevi yapan kişiler için geçerli olan m.573-576 hükümlerine göre dâva açılamaz ${ }^{26}$. Ancak, savcının sözkonusu faaliyetleri nedeniyle hizmet kusuruna dayanarak Adalet Bakanlığı'na karşı idare mahkemesinde tam yargı dâvası açılabileceği gibi ${ }^{27}$, şahsî kusurun varlığı halinde haksız fiillere ilişkin hükümlere göre hukuk mahkemelerinde tazminat dâvası da açılabi$\operatorname{lir}^{28}$.

Sorumluluk dâvası, tek başına yargılama yapan ve hüküm veren hâkim aleyhine açılabileceği gibi, toplu olarak yargılama yapan ve hüküm veren mahkeme üyeleri aleyhine de açılabilir ${ }^{29}$. Verilen karar mahkeme üyelerinin tümünün kararı olduğu için, mahkeme üyelerinin tümüne karşı dâva açılmalıdır; bir tek üye seçilerek dâva edilemez. Ancak, üyelerden biri vakıa ve belgeleri tahrif ederek mahkemenin kararına etkili olmuşsa, sadece onun aleyhine tazminat dâvası açılabilmelidir. Kararın toplu mahkeme tarafından verilmesi halinde, mahkeme üyeleri aleyhine dâva açılması üzerine, o kararı benimsemediğini belirten ve karar altına muhalefet şerhi veren kurul üyesi, kendisi hakkında sorumluluk için gerekli şartlanın gerçekleşmediğini isbat ederek sorumluluktan kurtulabilmelidir ${ }^{30}$.

2797 sayılı Yargıtay Kanunu'nun 26'ncı maddesine göre, "tetkik hâkimleri, kurul ve daire başkanlarının kendilerine verecekleri dosya ve evrakı, süresinde inceleyerek bir rapor düzenlerler. Karar-

23. Kunter, s.423 vd.

24. Öztüik, Bahri: Uygulamali Ceza Muhakemesi Hukuku, 3. B., Ankara 1994, s. 174.

25. Tosun, Öztekin: Türk Suç Muhakemesi Hukuku Dersleri, C.I, Genel Kısım, 4.B., Istanbul 1984, s.584.

26. Kuru Baki: Hukuk Muhakemeleri Usûlị, C.I, 5.B., Ankara 1990, s.590 (Kun 1); Bilge s.88; Doğanay s.673-674.

27. Kun IV s.3943; 4.HD 18.5.1965, $2459 / 2689$ (Ersoy, Rufat: Izahlı, Içtihath Hukuk Usalii Muhakemeleri Kanunu, Ankara 1966, s.539).

28. Bilge s.88; Ansay, Sabri Şâkir: Hukuk Yargılama Usûlleri, 7.B., Ankara 1960, s.48; Kuru I s.590.

29. E. Belgesay s.54.

30. E. Belgesay s.54. 
lara ve yapılacak işlere ilişkin düşüncelerini rapora yazıp kurullara açıklamakla yetinirler. Birinci Başkan, kurul ve daire başkanlarının verecekleri görevleri yerine getirirler". Görüldüği gibi, tetkik hâkimleri, daire ve kurulların karar verebilmeleri için yapılması gerekli olan önçalışmaları yapmak, daire ve kurulların ne yapması gerektiği konusunda görüş ve düşüncelerini bildirmekle görevlidir. Yoksa, ilk derece hâkimleri gibi, bir uyuşmazlığı çözïmleyen ve "kesinlik" niteliği taşıyan bir karar vermemektedirler. Sadece, neler yapıldığı ve neler yapılması gerektiği konusunda daire ve kurullara görüş ve düşüncelerini bir raporla bildirmektedirler. Bu rapor, tetkik hâkimini hukuken (m.573) sorumlu tutmak için yeterli değildir. Zira, raporu alan daire veya kurul, raporda belirtilen görüis ve düşünceleri benimseyerek o yönde bir karar verirse, artık sorumluluk tetkik hâkiminin değil, kararı veren daire veya kurula ait olur. Tetkik hâkimi görüş ve đüşünce bildirmekle, ilk derece hâkimleri gibi yargısal bir faaliyette de bulunmamaktadır. Aynca, tetkik hâkiminin hukukî sorumluluğundan sözedebilmek için, haksız fiil sorumluluğunun unsurlarından olan "zarar" ve "nedensellik bağı" (illiyet) şartı gerçekleşmelidir ${ }^{31}$. Oysa, burada, zarar ortaya çıkarsa, bu tetkik hâkkiminin raporuyla değil, rapor doğrultusunda karar veren daire veya kurulun kararıyla ortaya çıkmaktadır. Dolayısıyla sorumluluğun şartları daire veya kurulun karar vermesiyle gerçekleşmektedir. Bu nedenlerle, tetkik hâkimlerinin, daire veya kurullara verdikleri raporlardan dolayı m.573-576 hükümlerine göre sorumluluğu yoluna gidilememelidir. Şartları gerçekleşirse, disiplin sorumluluğu sözkonusu olabilir.

Hâkimlerin hukukî sorumluluğuna ilişkin m.573-576 hükümleri, kişiler arasında çıkan uyuşmazlıkları çözümleyen, onların sübjektif haklarun tespit için kanundan yetki alan bütün görevliler hakkında uygulama alanı bulur. Ancak, zabıt kâtibi, icra müdürü, tanık, bilirkişi gibi yargılama faaliyetinde bulunmayan diğer kimseler için sözkonusu hükümler uygulama alanı bulamaz ${ }^{32}$.

Hâkimlerin hukukî sorumluluğuna ilişkin hüiümlerin uygulama alanı belirlenirken, Medenî Kanun'daki vesayet organlarının sorumluluğuna ilişkin hiikümlere de kısaça değinmek yararlı olacaktır: MK m.409'a göre, hâkimler "vesâyet uzvu" sıfatı ile kast veya ihmal ile sebebiyet verdikleri zararlardan sorumludurlar. Bu hüküm

31. Bu konuda bkz. Tercan s.60 vd.

32. Bilge s.88. 
de, dolaylı olarak hâkimin sorumluluğuna iliskin bir hüküm olmakla beraber, buradaki sorumluluk, m.573-576 hükümlerine değil, Borçlar Kanunu'nun haksız fiillere ilişkin hükümlerine göre belirlenmelidir ${ }^{33}$.

\section{YÜKSEK YARGI ORGANLARININ BAŞKAN VE ÜYELERI}

\section{Yargitay Başkan ve Üyeleri}

HUMK m.573'deki "hâkim....aleyhine...tazminat dâvası ikame olunabilir" hükmündeki "hâkim" kavramına yüksek yargı organlarunda görevli hâkimler de dahil midir? Bu konuda HUMK'da açık bịr hüküm olmadığı gibi, bir başka düzenleme de yoktur. Bu nedenle doktrinde farklı görüşler ortaya çıktığı gibi ${ }^{34}$, Yargıtay hukuk dairelerinin ve Hukuk Genel Kurulu'nun verdiği kararlar arasında da zaman zaman farklı göriişlere rastlanmaktadır ${ }^{35}$.

Konuyu, 1221 sayilı Temyiz Mahkemesi Teşkilâtına Dair Kanun'un yürürlükte olduğu dönem ve 1730 sayılı Yargitay Kanunu ile, 2797 sayılı Yargıtay Kanunu'nun yürrïlükte olduğ́u dönem olmak üzere iki bölümde inceleyeceğiz:

1. 1221 sayılı Temyiz Mahkemesi Teşkilâtına Dair Kanun'un Yürürlükte Olduğu Dönem

Bu dönemde, 1221 sayılı Kanunda ve HUMK'da Yargıtay Başkan ve üyeleri aleyhine açılacak tazminat dâvasının nerede açılacağı konusunda bir hüküim mevcut değildi. Kanunkoyucunun susmasının, bu mahkemelerin başkan ve üyelerine karşı hukukî sorumluluk dâvasının açılamayacağı şeklinde yorumlanabilip yorumlanamayacağı tartışılmıştı. Bu konuda, Yargıtay'ın değişik kararları mevcut olduğu gibi, doktrinde de aşağıda değineceğimiz gibi, değişik göruişler ortaya çıkmıştı.

33. E. Belgesay s.51.

34. Örneģin bkz. Kuru IV s.3957 vd.; Postacıoğlu s.74; Özdeş, Orhan: Hâkimlerin Hukukî Sorumluluğu ve Devlet (Danıştay Der., 1971/2, s.13).

35. Örneğin, HGK 17.9.1975, 1974-2/3 (Kuntman, Osman: Hâkimlerin Hukukî Sorumluluğu (Gün. Yar. 1976/1, s.20-25); HGK 8.5.1974, 1/1 (YKD 1975/10, s.22-23); HGK 14.1.1987, 1/1 (YKD 1987/6, C.XIII, s.828-833).

36. Dinçer, Selami/Kazanc1, Sadi/Ersoy, Rufat: Hukuk Usûlü Muhakemeleri Kanunu, Ankara 1954, s.417. 
4. HD, 2.1.1946, 5220/67 sayılı kararinda ${ }^{36}$, yüksek yargi organlannda görevli hâkimlere karşı açılan tazminat dâvalarına bakmak için Yargitay dairesinin görevini kabul etmezken; 29.1.1959, 1386/963 sayılı kararında ${ }^{37}$ "hâkim" kavramını, yargı hakkını kullanan herkesi kapsayacak şekilde geniş yorumlamıştı. Bu karardan; yüksek yargı organlarının başkan ve üyeleri aleyhine tazminat dâvasının açılabilmesi gerektiği ve bu dâvanın Yargıtay'da açılabileceği; zira, sözkonusu dâvanın, idareye karşı açılmış idarî bir dâva olmayacağı, aksine haksız fiilden dolayı hâkime karşı açılmış tazminat dâvasına benzer bir dâva olduğundan, bunun ancak Yarg1tay'da açılabileceği sonucu çıkarılmıştı ${ }^{38}$.

Yargıtay Başkan ve üyelerinin hukukî sorumluluklarnna ilişkin dâvanın nerede açılacağı konusunda kanunda doldurulması gereken bir boşluğun varlığı kabul edilmişti. 3 . HD bu konuda şöyle bir karar vermişti: 'Yargıtay'ın bir dairesini teşkil eden başkan ve üyeler için de, Yargıtay Hukuk Genel Kurulu'nun veya Büyük Genel Kurul'un görevli olması akla ve mantığa uygun olur; fakat, mahkemelerin görevlerini kıyas yolu ile belirlemek mümkün değildir. Bu nedenle sözkonusu çözümün kabul edilemeyeceği açıktır. Yargitay Başkan ve üyeleri aleyhine HUMK m.573-576 hükümlerine göre bir tazminat dâvası açılamayacağı, bu gibi dâvalar için yeni bir kanunla görevli makam belirleninceye kadar ancak Anayasa Mahkemesi'ne kamu davası açılması ve bu davaya müdahale etmek suretiyle tazminat istemenin (44 s.K. m.34; CMUK m.365-372) mümkün olduğu belirtilmişti ${ }^{39}$.

Doktrinde, bu konuya ilişkin olarak şu görüs savunuluyordu: Yargıtay Başkan ve üyelerinin hukukî sorumluluğu konusunda bir hüküm bulunmaması, bu kimseler aleyhine HUMK m.573-576 hükümlerine göre, tazminat dâvası açılamaz şeklinde yorumlanmamalıdır. HUMK m.573'deki "hâkim" kavramına Yargıtay Başkan ve üyeleri de dahildir. Bu sebeple, sözkonusu kişiler aleyhine açllacak tazminat dâvaları hakkında 4.HD görevli olmalı, bu dairenin kararlarına karşı da Hukuk Genel Kurulu temyiz mercii olarak kabul edilmelidir ${ }^{40}$. Tazminat davası bir dairenin bütün üyeleri aleyhine

37. Son tçt. 1959/134, s.3899.

38. Kurti, Baki: Hukuk Muhakemeleri Usîllä, 2.B., Ankara 1968, s.766-767 (Kuru-Usôl 1968).

39. 3. HD 24.12.1963, 3381/9098 (AD 1964/3-4, s.4402-4405).

40. Kunu-Usûl 1968, s.766. 
açılırsa, bu halde dâvaya HGK bakmalı, bu kurulun kararlarının temyiz incelemesi Büyük Genel Kurulda yapılmalıdır ${ }^{41}$.

Eğer, Yargıtay ïyelerine karşı tazminat dâvasını görecek makamın belirlenmemiş olmasından, bu kişiler aleyhine tazminat davasının kesin olarak açılamayacağı sonucu çıkarılacaksa, o takdirde, sözkonusu kişiler aleyhine ceza dâvasına başvurma imkânt tanınmalıdır ${ }^{42}$. Ancak, böyle bir imkânın tanınması her zaman mümkün değildir; bu konuda bir kanun boşluğu olduğu açıkıı ${ }^{43}$. Bu boşluk mahkemelerin görevlerinin kıyas yolu ile belirlenemeyeceği kuralı nedeniyle de Yargıtay tarafından doldurulamamıştır.

2- 1730 sayılı ve 2797 sayılı Yargitay Kanunlarnnı Yürürlükte Olduğu Dönem

27.5.1973 tarihinde yürürlüğe giren 1730 sayılı eski Yargıtay Kanunu hazırlanı̣ken yukarıda değinilen göreve ilişkin kanun boşluğu dikkate alınmış ve 1730 s.K.m.3/2 ve 17/3'de Yargıtay Başkan ve üyeleri aleyhine açılacak hukukî sorumluluk dâvalarında görevli mercii olarak, Yargıtay Hukuk Genel Kurulu gösterilmiştir. Böylece, 1221 s.K. dönemindeki sorumluluk dâvasının nerede açılacağına ilişkin kanun boşluğu doldurulmuş olmaktaydt. 1730 s.K.'da aynca, sorumluluk dâvalannda ilk derece mahkemesi olarak özel dairelerin verdikleri kararlara karşı temyiz merciinin neresi olacağı da belirlenmişti (1730 s.K. m.17/3).

1730 s. Yargitay Kanunu, 8 Şubat 1983 tarihinde yürürlüğe giren $2797 \mathrm{~s}$. Yargitay Kanunu'nun 68'nci maddesi ile yürürlükten kaldırılmıştır. Ancak, 1730 s.K.m.3/2 ve 17/3'deki Yargıtay Başkan ve üyeleri ile kanunen onlar durumunda bulunan kişilere karşı $\mathrm{Hu}-$ kuk Genel Kurulu'nda dâva açılabileceğine ilişkin düzenleme, halen yürürllikikte olan $2797 \mathrm{~s}$. Yargıtay Kanunu'nda da aynı şekilde tekrarlanmıştır. Gerçekten, 2797 s.K.m.13/2 hükmü "Yargıtay Başkan ve üyeleri ile Yargitay Cumhuriyeti Başsavcısı, Yargitay Cumhuriyet Başsaveı vekili ve özel kanunlarında belirtilen kimseler aleyhindeki görevden doğan tazminat dâvalarına ve bunların kişisel suçlarına ait ceza dâvalarına ve kanunlarda gösterilen diğer dâvalara ilk ve son derece mahkemesi olarak bakmak" şeklinde kaleme

41. Postacıoğlu, Ilthan: Medenî Usûl Hukuku Dersleri, 4.B., Istanbul 1968, s.71-72 (Postacıoğlu 1968).

42. Postacioglu 1968, s.72.

43. Bilge 5.92 . 
alınmış olup, 1730 s.K.m.3/2 hükmüi ile aralarında anlam bakımından hiçbir farklılık olmayıp, sadece ifadede küçük değişiklikler vardır. Keza, 2797 s.K.m. 15/3 hükmü de "Yargıtay Başkan ve üyeleri, Cumhuriyet Başsavcısı ve Yargıtay Cumhuriyet Başsavcı Vekili ile yargılama görevi özel kanunlarınca Yargıtay Genel Kurullarına verilen kişilere ait dâvaları ilk mahkeme olarak görmek ve hükme bağlamak ve ilk mahkeme olarak özel dairelerce verilen hüküm ve kararların temyiz ve itiraz yoluyla incelenmesini yapmak" şeklinde kaleme alınmış olup, 1730 s. K.m.17/3 hükmü ile arasında anlam bakımından yine bir farklılık yoktur ${ }^{44}$. Bu nedenle, 1730 s. eski Yargitay Kanunu'nun getirdiği düzenleme ile, halen yürürlükte olan 2797 s. Yargitay Kanunu'nun getirmiş olduğu düzenlemeyi birlikte inceliyoruz.

1730 s.K. m.3/2 ve 17/3'e dayanılarak Yargıtay Başkan ve üyeleri aleyhine m.573-576 hüikümlerine göre sorumluluk davası açılabileceği doktrinde savunulmuştu ${ }^{45}$. Yargıtay Hukuk Genel Kurulu $\mathrm{da}$, gerçi karara konu olan olayda, dâva dilekçesi m.575'de öngörülen şartlan taşımadığı için reddedilmekle beraber, bu kanunî düzenlemeyi (1730 s.K. m.3/2 ve 17/3) gözönüne alarak Yargıtay Başkan ve üyeleri aleyhine Hukuk Genel Kurulu'nda doğrudan doğruya tazminat dâvası açılabileceğini kural olarak kabul etmişti ${ }^{46}$. Hukuk Genel Kurulu'nun bu karan hem kanunî dỉzenlemeye uygundu, hem de doktrinde benimsenmişti ${ }^{47}$. Ancak, Hukuk Genel Kurulu 14.1.1976, 5/4 sayılı kararıyla ${ }^{48}$ m.573-576 hükümlerine göre Yargıtay Başkan ve üyeleri aleyhine sorumluluk dâvası açılamayacağına karar vermiştir. HGK, $30.11 .1984,1 / 1^{49}$ ve $14.1 .1987,1 / 1^{50}$ sayılı kararlàrında, 14.1.1976, 5/4 sayılı karan emsâl kabul ederek, aynı görüşü aynı gerekçelerle tekrar savunmuştur. Sözkonusu kararların gerekçesi de aynı olduğundan, sadece $30.11 .1984,1 / 1$ sayılı kararın metnini kısaca aktarmak istiyoruz:

44. Aynı yönde Kuru IV s. 3960-3961; Üstündă̌ s. 112-113; Doğanay s.698.

45. Kuru, Baki: Hukuk Muhakemeleri Usâlï, 3.B., Ankara 1974, s.1038-1039; Bilge, Necip/Önen, Ergun: Medenî Yargllama Hukuku Dersleri, 3.B., Ankara 1978, s.106; Berkin, Necmeddin: Tatbikatçıara Icra Hukuku Rehberi, Istanbul 1980, s.44.

46. HGK 8.5.1974, 1/1 (YKD 1975/10, s.22-23); HGK 6.10.1973, 1/1 (Kuru IV s.3958).

47. Kuru IV s.3957-3960; Bilge/Önen s.107; Kılıçö̌lu s.240.

48. YKD 1976/6, s.787-790; ABD 1976/6, s. 1084-1087.

49. Is. BD 1985/1-3, s.188-204; Kuru Baki: Hukuk Muhakemeleri Usalü, C.V., Ankara 1986, s.4681-4689; Kun IV s.4388-4391.

50. YKD 1987/6, s.828-832. 
Hukuk Genel Kurulu, bu kararında Yüksek Seçim Kurulundaki görevevleri nedeniyle Yargıtay ve Danıştay Başkan ve üyeleri aleyhine açılan sorumluluk dâvasında, kural olarak Yargıtay Hukuk Genel Kurulu'nun görevli olduğunu kabul etmiştir. 2797 s. Yargıtay K. m. $13 / 2$ ve $15 / 3$ 'de sorumluluk dâvasına bakacak merciin belirtildiğini, ancak başkan ve üyelerin hangi hallerde sorumlu tutulacaklarının özel olarak tespit edilmediğini ve diğer hâkimler hakkındaki kurallara da gönderme yapılmadığını belirtmektedir. "Bu konuda bidayet mahkemesi hâkimleri hakkında düzenlemede bulunan $\mathrm{Hu}$ kuk Usûlü Muhakemeleri Kanunu'nun 573 ve müteakip maddelerindeki sorumluluk hallerinin Yargıtay iuyeleri hakkında uygulanıp uygulanmayacağı incelenmelidir. Bu maddelerle Yargıtay üyelerinden sözedilmediğinden 573 'üncü maddedeki "hâkim" sözünün de sorumluluk açısından sadece 575/2'nci maddede sayılanları hedef tuttuğunun kabulï gerekir. Zira, 573 ve bunu izleyen maddelerin tedvini sırasında hâkimlerin sorumlulukları sistemi içerisinde Yargitay üyelerine değinilmediği ve onlar hakkında düzenlemede bulunulmadığı halde 573'ncii maddedeki "hâkim" sözünün Yargitay üyelerini de kapsamına aldığının düşüinülmesi yorum kuralları ile bağdaştırilamaz. Bu açıklamalardan Hukuk Usûfü Muhakemeleri Kanunu'ndaki sorumluluk hallerinin Yargttay üyelerini kapsamadı$\breve{g}_{1}$ sonucuna varmak gerekir... Diğer taraftan Usolün 573 ve müteakip maddeleri iștisnaî ve sınırlı bir alanda düzenlemede bulunduğundan kıyas yolu ile uygulama alanının genişletilmesi de mümkün değildir. O halde Yargitay üyeleri hakkında hangi hallerde görevden dolayı tazminat dâvası açılacağının yasa ile belirlendiğinden söz edilemez. -Bu durum karşısında sorun temel dïzeni oluşturan Anayasa ve genel ilkeler esas alınarak çözümlenmelidir." Yasaların uygulanmasında Anayasanın 11 'nci maddesinde öngörülen Anayasanın üstünlüğüi ilkesinin sonucu olarak onların Anayasa ilkelerinin ışığında değerlendirilmeleri, yorumlanmaları zorunludur. Anayasa 148/3'üncui maddesinde Yargıtay ve Danıştay Başkan ve üyelerinin görevleri ile ilgili suçlardan dolayı yargılanmalarının "Yüce Divan" sıfatı ile Anayasa Mahkemesinde yapılacağı belirtilmiştir. Buradaki amaç yargılanacak kişiyi değil, kurumu korumak olup doğrudan doğruya kamu düzenini ilgilendirmesi nedeniyle Yüce Divan'da yargılanması gereken kişinin bundan feragatı da hukukî sonuç doğurmaz. Bu nedenlerle usûlen görevli mercii (Anayasa Mahkemesi) tarafından görevle ilgili suçtan cezâ̂ sorumluluk yönünden bir karar verilmeden Hukuk Genel Kurulu'nda açılan tazminat dâvasının reddi gerekir ${ }^{51}$.

51. HGK 30.11.1984, 1/1 (1s.BD 1985/1-3, s.188-204). 
Hukuk Genel Kurulu'nun bu kararlannı şu yönlerden eleştirmek mümkündür:

1- Hukuk Genel Kurulu, Yargitay Başkan ve üyeleri ile kanunen onlar,durumurida olan kişiler aleyhine hukukî sorumluluk dâvası açılabilmesi için Anayasa Mahkemesi'nden, tazminata neden olan fiilin aynı zamanda suç teşkil ettiğini ve dâva edilecek üyenin de bu fiilden dolayı cezalandırıldığını belirten bir mahkûmiyet karan getirilmesini, hukukî sorumluluk dâvasının "önşarti" (dâva şartı) olarak kabul etmektedir ${ }^{52,53}$. Bu durumda, görevle ilgili bir suçtan dolayı aleyhine mahkûmiyet karan verilmemiş Yargıtay Başkan ve üyesinin (ve kanunen onlar durumunda olan kimselerin) hukukî sorumluluğu sözkonusu olmayacak demektir ${ }^{54}$. Oysa, hukukî sorumluluk için, kural olarak aynı fiilden mahkûm edilmiş olmak şart değildir. Nitekim, ilk derece hâkimlerinin m.573-576 hüküimlerine göre hukuken sorumlu tutulabilmeleri için görevleriyle ilgili ve zararın doğmasına neden olan fiilden dolayı cezalandırılmış olmaları gerekmemektedir. Yoksa, gerçekten zarara uğrayan kimseyi, bu zarann tazmin edilmesi için Anayasa Mahkemesi'nde ceza dâvası açmaya ve bu davayı kazanmaya zorlamak, yargı denetiminin açıkca önlenmesi ve hak arama özgürlüğünün kısıtlanması anlamına gelirdi ki, bu durumun "hukuk devleti" ilkesine zarar vereceği açıktır.

2- Anayasa'nın 148/3'üncü maddesine göre Anayasa Mahkemesi'nin, Yargıtay Başkan ve üyelerini, görevlerinden doğan suçlardan dolayı "Yüice Divan" sıfatıyla yargılayabilmesi için usûlüne uygun olarak bir dâva açılması gerekir. Anayasa'nın 150'nci maddesi, Anayasa Mahkemesi'nde doğrudan doğruya dâva açabilme hakkını, kanunların, kanun hükmünde kararnamelerin, Türkìye Büyük Millet Meclisi İçtüzügüünün veya bunların belirli madde ve hükümlerinin iptali için, Cumhurbaşkanına, iktidar ve anamuhalefet

52. Bilge/Önen s.108; Doğanay s.699; Kuntman s.25; Çetin Aş̧ı̆ğlu'nun, HGK 14.1.1987 tarih ve 1/I nolu karara verdiği muhalefet şerhi (YKD 1987/6, \$.833); Acar, Bülent: Yargıtay'ın Başkan ve Üyelerinin Hukuksal Sorumsuzluğa Yaklaşan Sonumluluklarına lliş̧kin Görüş̧iniủn Eleştirisi (TBBD, 1990/, s.502).

53. İviçre'de, Federal Meclis tarafindan seçilen, Fèderal Mahkeme đ̈yeleri, olağanülstił askerî mahkeme ilyeleri, federal devlet başkani gibi kimselere karşı, bunlarn eylemlerinden zarar gören üçünciu kişiler dâva açabilmek için önce Federal Meclisten "takip yetkisi" almak zorundadirlar, bu yetki verilmezse, bu takdirde taleplerini devlete karş1 yöneltmektedirler (Kaufman s.211a-212a). Keza, Waadt ve Fribourg kantonłannda, kanton hâkimine karşı dâva açabilmek için hükửmetin, eyalet hâkimine karşı dâva açabilmek için de Kanton mahkemesinin izni gerekmektedir (Kaufman s.245a; Guldener, Max: Schweizerisches Zjvilprozessrecht, 3.Aufl., Zlirich 1979, s.7).

54. Bilge/Önen, s.108. 
partisi meclis grupları ile Türkiye Büyük Millet Meclisi üye tam sayısının en az beşte biri tutarındaki üyelere tanımıştır. Bu durumda, dâvacının, davalı Yargıtay Başkan ve üyeleri aleyhine Anayasa Mahkemesi'nde doğrudan doğruya ceza dâvası açabilme hakkı yoktur. Davacının, dâvalılar aleyhine ceza dâvası açabilmesi için, önce 2797 s. Yargıtay Kanunu'nun 46'ncı maddesine göre Yargıtay Birinci Başkanlık Kurulu'na başvurması gerekir. Bu Kurul tarafından soruşturmaya gerek görülürse, o zaman soruşturma yapmak üzere bir ceza dairesi başkanı tayin edilir. Tayin edilen hâkim, yapacağı soruşturma sonunda, ilgili soruşturma evrakını Birinci Başkanlık Kurulu'na verir. Kurul, soruşturma evrakına göre son soruşturmanın açılmasına karar verirse, ancak o zaman Birinci Başkanlık $\mathrm{Ku}$ rulu ve Cumhuriyet Başsavcilığı aracılığıyla, Başsavcının hazırladığı iddianâme ile Anayasa Mahkemesi'nde dâvalı Yargıtay Başkan ve üyeleri aleyhine dâva açılabilecektir ${ }^{55}$. Birinci Başkanılık Kurulunun vereceği kararlar keşindir (2797 s.K. m.46). Bu durumda, Birinci Başkanlık Kurulu son soruşturmanın açılmasına gerek görmezse, davacı maddî ve manevî zarara uğramış olsa bile, bunu adlî yoldan tazmin ettiremeyecektir. Dolayısıyla, yargı yoluna başvurma ve hak arama özgürlüğü engellenmiş olacaktır.

3- Anayasa Mahkemesi'nden getirilmesi gereken cezaî sorumluluğa ilişkin karar m.575'de sayılan ve dava dilekçesine eklenmesi gereken belgelerden biri değildir ${ }^{56}$. HUMK m.575'e göre, dâva dilekçesinde, "...iki tarafın isim ve şöhret ve sıfat ve mahalli ikameti ve sebebi şikâyet olan davanın hülâsasıyla cereyan eden muhakemenin ve verilen hüküm ve kararlarla ifa olunan muamelenin hülâsaları ve tazminat davasının müstenidi olan esbab (m.573) ile bunların delâili sübutiyesinin ve talep ve dâva olunan zarar ve ziyantn neden ibaret olduğu yazılmak ve sebebi şikâyet olan đava zabıtnâmesiyle evrakı sübutiyesi ve şuhut pusulası işbu arzuhale merbuten verilmek lâzımdır." Görüildüğui gibi, dâva dilekçesine eklenmesi gereken belgeler, duruşma tutanakları, tanık listesi ve diğer ispat araçlarından ibarettir. Bu belgeler, dâva dilekçesine eklenmezse, dâva dilekçesi reddolunur (m.575/1 son c.). HUMK, dâva dilekçesine eklenmediğinde dilekçenin reddine sebep olan belgeleri tahdidî bir şekilde belirlemiştir. Bu belgelere, yenilerini ekleyerek örneğin, Anayasa Mahkemesi'nden getirilecek cezaî sorumluluğa ilişkin belgenin de dilekçeye eklenmemesi nedeniyle dilekçeyi reddetmek,

55. Doğanay s.712.

56. Doğanay $\mathrm{s.} 700$. 
kanuna aykín bir davranış olur. Ayrıca, Anayasa Mahakemesi'nden getirilecek cezaî sorumluluğa ilişskin belge, 575 'inci maddede geçen "evrakı sübutiye" kavramına dâhil edilmemelidir.

4- Hukuk Genel Kurulu, bu kararıyla, m.573'deki "hâkim" kavramına Yargıtay Başkan ve üyelerini dahil etmeyerek hukuka ve yorum kurallarına aykırı davranmıştır. Zira, Anayasa 9'uncu maddesinde, yargı yetkisini bir bütün olarak kabul etmiş ve bu yetkinin, Türk Milleti adına bağımsız mahkemelerce kullanılacağı kuralını koymuştur. "Yargı" başlığını taşıyan üçüncü bölümde, yargıya ve yüksek yargı organlarına iliş̧in hükümlere yer vermiş̧tir. Yargı yetkisini kullanan bağımsız mahkemeler kavramına, hem ilk derece hâkimlerinin, hem de yüksek yargı organlannda görevli hâkimlerin girdiğinden şüphe yoktur ${ }^{57} .2802 \mathrm{~s}$. Hâkimler ve Savcılar Kanunu m.15/1, hâkimleri dört sınıfa ayırmıştır. Yargıtay Başkan ve üyeleri birinci sınıf hâkimlerdir (Anayasa m.154/2, 2802 s.K. Ek 1 sayılı Cetvel). Aksi takdirde, hem Anayasa m.140 hükmünün, hem de 2797 s. K.m. 15/3 hükmünün bir anlamı kalmazdı. HUMK m.573'deki "hâkim" kavramı, birinci sınıf hâkimlerle, diğer ikinci ve üçüncü sınıfları oluşturan hâkimler arasında bir ayırım gözetmediğine göre "hâkim" kavramına Yargıtay Başkan ve üyeleri de dahil olmalıdır ${ }^{58}$. Ancak, yargılamayı yapacak merci için özel hükümler konulmuş olduğundan (797 s. K.m.13/2; 15/3; HUMK m.575), ilk derece hẩkimleriyle yüksek yargı organlarında görevli hâkimlerin yargilanması farklı yerlerde yapilacaktır.

5- Hukuk Genel Kurulu, sözkonusu kararlanyla Yargıtay Kanunu $\mathrm{m} .15 / 3$ hükmü ile kendisine yüklenen yargılama görevini Anayasa Mahkemesi'ne dolaylı olarak aktarmaktadır. Zira, dâvanın Anayasa Mahkemesi'nde görülebileceğini kabul ettiğimizde, dâvacıya, Anayasa Mahkemesi'nde açlan ceza dâvasına, suçtan zarar gören kimse sıfatı ile CMUK m. 365 vd. maddelerine göre katılabilme ve TCK m.38'e göre Hukuk Genel Kurulu'ndan isteyemediği tazminatı da hüküm altına aldırma imkânı ortaya çıkar. Bu durumda, Anayasa Mahakemesi'nden sonra aynca bir de Hukuk Genel Kurulu'nda dâva açmaya gerek yoktur. Zira dâvacı, Hukuk Genel Kurulu'ndan isteyemediği zararı Anayasa Mahkemesi'nin kararı ile hüküm altına aldırmış olacaktır. Ayrıca, dâva sabit olmadığı takdir-

57. Bilge/Önen s.107.

58. Kuru IV s.3960; Bilge/Önen s.107; Ustündağ s.112-113; Doğanay s.699; Hallą̧ s.58; Acar 3.495 vd. 
de, dâvacının para cezasına çarptırılmasına ve dâvalı hâkimin uğradığı maddî ve manevî zarar için mahkemece uygun bir tazminata hükmedilmesine ilişkin HUMK m.576/2 hükmü zımnen ilga edilmiş olacaktır ${ }^{59}$.

6- Yargıtay üyelerinden bazıları, Yargıtay özel dairelerinde verilecek kararlardan dolayı, ilgili kişilerin o karan veren daire aleyhine dâva açabilme yolunun açık tutulması halinde, bu yolun suistimal edileceği ve her önüne gelenin o kararı veren daire aleyhine tazminat dâvası açma yoluna gideceği varsayımını belirtmişler ve bu nedenle Anayasa Mahkemesi'nden Yüce Divan sıfatıyla cezaî sorumluluğa ilişsin karar getirilmesinin yerinde olacağı fikrini ileri sürmüşlerdir. Böyle bir varsayım kabul edilemez. Cünküi, kanunkoyucu böyle bir suistimali önlemek için $\mathrm{m} .576$, II hükmünü koymuştur. Bu hükme göre, bir kimse Yargıtay Başkan ve üyeleri aleyhine açacağı davayı kaybederse, o zaman Hukuk genel Kurulu dâvacıyı hem para cezasına, hem de davalı hâkimlerin uğradıkları zararlar için uygun bir tazminata mahkûm eder. Görüldüğg̈ gibì, m.576, II hükmü ile sözkonusu dâva açma hakkının suistimal edilmesi ihtimali kanunkoyucu tarafından önceden önlenmiş bulunmaktadır ${ }^{60}$. Ayrıca, yüksek yargı organlarında görev yapan hâkimler aleyhine açılan hukukî sorumluluk dâvası zannedildiği kadar çok da değildir. 1730 s. Yargttay Kanunu'nun yürürlüğe giriş tarihi olan 1 Haziran 1973 tarihinden sonra bu güne kadar, Hukuk Genel Kurulunda 24 adedi Yargıtay, 3 adedi Danıştay, 1 adedi Yüksek Seçim Kurulu, 1 adedi Askerî Yüksek Îdare Mahkemesi, 1 adedi de Yüksek Hâkimler Kurulu Başkan ve üyeleri hakkında olmak üzere toplam 30 dâva açılmışıır ${ }^{61}$.

7- Sözleşmeye dayalı sorumluluğun dışında, haksız fiil sorumluluğu, genel olarak, kusura dayanır (BK m.41). Eğer, Yargıtay Başkan ve üyeleri için, görevlerinden dolayı özel sorumluluk nedenlerinin (m.573) öngörülmediği kabul edilecek olursa, bu takdirde, genel olarak kusura dayalı sorumluluk (BK m.41) uygulama alanı bulmalıdır ${ }^{62}$. Bu durum ise, yüksek yargı organlarında görev yapan hâkimler için daha ağır bir sorumluluktur. Oysa HUMK, hâkimin bağımsızlığı kadar tarafsızlığını da güvence altına almak

59. 30.11.1984, 1/1 sayılı karara verilen muhalefet şerhi (Doğanay s.710).

60. Doğanay $\$ .712$.

61. HGK I4.1.1987, 1/1 (YKD 1987/6 s.832).

62. Acar 5.503 . 
amaci ile onun hukukî sorumluluğunu sinırlı hallerde (m.573) kabul etmiş ve aynı zamanda sorumluluğun tesbitini özel bir usûle tâbi tutmuştur ${ }^{63}$. Ayrıca, BK m.41'de öngörülen kusur sorumluluğu, kanunkoyucu tarafından bazı hallerde ağurlaştırılmış, bazen de hafifletilmiş veya sınırlandırılmıştır. Bütün bu durumların gerçekleşebilmesi için özel bir düzenlemenin varlığı zarurîdir. Oysa, Hukuk Genel Kurulu, Yargıtay Başkan ve üyelerinin sorumluluk nedenleri konusunda kanun boşluğunun varlığını kabul ederek, sözkonusu kimselerin sorumluluğuna ilişkin olarak yeni ve kanunkoyucu tarafından öngörülmeyen bir durum ortaya çikarmaktadır. Hukuk Genel Kurulu'nun böyle bir yetkiye sahip olduğu söyleneme ${ }^{64}$.

Bu nedenlerle, m.573'de belirtilen "hâkim" kavramına sadece 575 , II'de belirtilen ilk derece hâkimleri değil, yargılama görevi yapan diğer yüksek yargı organlarında görevli hâkimler de dahil edilmelidir. Bunun sonucu olarak, Yargıtay Başkan ve üyeleri (ve kanụnen onlar durumunda bulunan kimseler) aleyhine doğrudan doğruya Hukuk Genel Kurulu'nda m.573-576 hükümlerịne göre tazminat dâvası açılabilmeli ve dâvanın görülebilmesi için de Anayasa Mahkemesi'nden alınacak cezaî sorumluluğa ilişkin karar aranmamalidir $^{65}$.

Hukuk Genel Kurulu, Yargıtay Başkan ve üyeleri ile yargılama görevi özel kanunlarınca Hukuk Genel Kurulu'na verilen kişilere ait dâvaları ilk derece mahkemesi olarak görür ve karara bağlar (Yargitay K. m.15/3). Yargitay Kanunu, Hukuk Genel Kurulu'nun ilk derece mahkemesi olarak verdiği kararlar için temyiz mercii öngörmemiştir. Bunun nedeni, Hukuk Genel Kurulu'nun verdiği kararların hatasız olacağı ve bu nedenle tekrar incelenmesine gerek olmadığının kanunkoyucu tarafından kabul edilmesidir. Nitekim, 1730 s. eski Yargitay Kanunu m.17/3'de, Hukuk Genel Kurulu'nun sözkonusu dâvaları "kesin" olarak karara bağlamasını kabul etmiş$\mathrm{ti}^{66} .2797$ s. Yargitay Kanunu'nun, Yargitay Büyük Genel Kurulu'nun görevlerine ilişkin 16'ncı maddesinde de Hukuk Genel Kuru-

63. HGK 14.1.1987, $1 / 1$ (YKD 1987/6 s.829).

64. Acar s.505; Asçioglu s.833.

65. Kuru IV s.3961; Üstündał s.112-113; Postacığlu s.74; Bijge/Önen s.107-108; Önen, Ergun: Medenî Yargilama Hukuku, Ankara 1979, s.18; Kuntman s.24-25; farklı gơ̆rüş için bkz. Özdeş s.13-14; Berkin, Necmeddin: Medenî Usul Hukuku Esaslari, Istanbul 1969, s.38.

66. "Buradaki kesinlik sözkonusu Genel Kurul kararlarma karşı hiçbir mercie ve hiçbir kanun yoluna başvurulamayacağını, başka bir anlatımla bu kararlarn son söz teşkil ettiğini ifade eder." HGK 8.5.1974, $1 / 1$ (YKD 1975/10, s.23). 
lu kararlarının temyiz edilebilmesine veya temyiz merciine ilişkin bir hüküm yoktur. Yargıtay Kanunu'nun 15/3 ve 16'ncı maddelerini birlikte degerlendirdiğimizde, Hukuk Genel Kurulu kararlarının kesin olarak verildiğini ve kanunkoyucunun temyiz merciini bu nedenle belirlemediğini söylemek mümkündür.

\section{II-Danıstay Başkan ve Üyeleri}

1730 s. eski Yargitay Kanunu'nun yürürlüğe girmesinden önce Danıştay Başkan ve üyeleri aleyhine sorumluluk davasının nerede açılacağı tespit edilmediğinden, kıyas yolu ile de görevli mercii belirlenemeyeceğinden, Yargıtay Başkan ve üyelerinde olduğu gibi, tazminat dâvasının Anayasa Mahkemesi'nde açılması savunuluyor$\mathrm{du}^{67}$. Ancak, 1730 s. eski Yargitay Kanunu ve onu takiben 2797 s. Yargitay Kanunu, bu görevi Yargitay Hukuk Genel Kurulu'na vermiştir. 1730 s. K.m. 17/3'deki "kanunlara göre onlar durumunda bulunan kimseler" ve 2797 s. K.m.15/3'deki "yargıllama görevi özel kanunlarınca Yargıtay Genel Kurullarına verilen kişiler" ifadesi Danıştay Başkan ve üyelerini de kapsamına almaktadır ${ }^{68}$. Nitekim, Hukuk Genel Kurulu 30.11.1984, 1/1 sayılı kararına göre, "....2575 sayı̣ı Danıştay Kanunu'nun 4'ncü maddesi hükmü teminat konusunu düzenleyerek "Danıştay Başkanı, Başsavcı, Başkan vekilleri, Daire Başkanları ve üyeleri, yüksek mahkeme hâkimleri olarak Türkiye Cumhuriyeti Anayasası ve Kanunların kendilerine sağladığı teminat altında görev yaparlar." Bu hükümlerle, maddede belirtilenlerin, yüksek mahkeme hâkimlerine Türkiye Cumhuriyeti Anayasası ve Kanunların sağladığı teminat altında görevlerini yürütecekleri açıklanmıştır. Yargıtay Kanunu'nun 13/2 ve 15/3 maddelerinde sayılanların görevlerinden doğan tazminat dâvalarının Yargitay Hukuk Genel Kurulu'nca görülmesi, kuş̧usuz yüksek mahkeme hâkimlerine sağlanan bir teminat niteliğindedir. Bu hükümlerin, Danıştay Başkanı, Başsavcı, Başkanvekilleri, Daire Başkanları ve üyeleri hakkında da uygulanması $2575 \mathrm{~s}$. Danıştay Kanunu'nun 4'üncü maddesi hükmii gereğidir" ${ }^{169}$. Bu durumda, Hukuk Genel Kurulu, Danıştay Başkan ve üyyeleri aleyhine açılacak tazminat dâvalarında kural olarak görevlidir.

Danıştay Başkan ve üyeleri aleyhine açılan sorumluluk dâvasının nerede görüleceği belirlenmiş olmasına rağmen, sözkonusu ki-

67. Özdeş s.13-14; Berkin-Usul s.38; Postacıoğlu, s.74.

68. Doğanay s.701; Bilge/Önen s.106.

69. Doğanay s.702. 
şiler aleyhine m.573-576 hükümlerine göre tazminat dâvasının açılabilip açılamayacağı tartışma konusu olmuştur.

Bir görüşe göre, Danıştay Başkan ve üyeleri aleyhine m.573576 hükümlerine göre dâva açılamaz. Çünkü:

1- Danıştay, Anayasa ile kurulmuş bağımsız yüksek bir idare mahkemesidir. Başkan ve üyeleri de Danıştay Kanunu'na tâbi olup, Hâkimler ve Savcılar Kanunu'nun kapsamı dişındadırlar. Bu sebeple, HUMK'nun kastettiği anlamdaki "hâkim" kavramına girmemektedirler. Danıştay Başkan ve üyelerini yargı görevini yaptıkları gerekçesi ile bir içtihatla HUMK kapsamına dahil etmeye imkân yoktur $^{70}$.

2- HUMK m.573, açıkca "hâkim ve icra reisi" aleyhine hangi hallerde tazminat dâvaşı açılabileceğini belirtmiştir. Sözkonusu maddede Danıştay Başkan ve üyelerinden sözedilmemiştir. Emredici bir hüküm olması nedeniyle, kıyasen Danıştay Başkan ve üyelerine de uygulanmasına hukuken imkân yoktur.

Bu nedenlerle, Danıştay Başkan ve üyeleri hakkında doğrudan tazminat dâvası açılamaz; görevleri ile ilgili olarak işledikleri bir suçtan dolayı açılacak kamu dâvasına, suçtan zarar gördügüünüi iddia eden kişi müdahale ederek zararının tazminini isteyebilir ${ }^{71}$.

Ayrıca, bu kişilerin Yargıtay üyelerinden oluşan bir kurul tarafından yargılanması, "kuvvetler aynlığı bakımından yürü̈rlükte olan kuralları ne bakımdan zedelemeyeceği izah ve ispatı gereken noktalar halinde kalmaktadıi" ${ }^{\prime 2}$.

Diğer bir görüşe göre, Danıştay Başkan ve üyeleri aleyhine HUMK m.573-576 hükümlerine göre tazminat dâvası açılabilir. Zira, HUMK m.573'deki "hâkim" kavramı, yargllama yetkisine sahip kişilere ilişkindir ${ }^{73}$. Anayasa 9'uncu maddesinde, yargılama yetkisinin bir bütün olarak Türk Milleti adına bağımsız mahkemelerce kullanılacağını belirtmiştir. Anayasa 3 'üncü bölümünde de yargı yetkisini kullanacak mahkemeleri belirlemiştir. Burada, sádece adlî mahkemelere yer verilmeyerek, "hâkim" kavramının da adliye

70. Özdes s.13-14.

71. Öżdeş s. 14; Berkin-Usul, s.38.

72. Postaciog Ju s.74.

73. Kuru IV s.3961. 
mahkemesi hâkimlerine ait olmadığı anlatılmıştır ${ }^{74}$. Danıştay Başkan ve üyelerinin "hâkim" kavramına dahil oldukları, 4. HD 1.6.1970, 3699/4536 sayılı kararı ${ }^{75}$ ile de sabittir. Zira, Danıştay Başkan ve üyeleri, sözkonusu kararla, hâkimlerin, hakemlik yapamayacaklarına ilişkin 13.5.1964 tarihli içtihadı birleştirme kararının ${ }^{76}$ kapsamına dahil edildiklerinden, o günden beri hakemlik de yapamamaktadirlar.

Bu nedenlerle, Yargıtay Başkan ve üyelerinin hukukî sorumluluğunun kabul edilmesi için belirtilen gerekçeleri de gözönüne alarak, Danıştay Başkan ve üyelerinin (ve yargısal faaliyette bulunan Sayıştay, Yükssek Seçim Kurulu gibi diğer yüksek yargı organlarının başkan ve üyelerinin) aleyhine, yargısal faaliyetlerinden dolayı m.573-576 hiikümlerine göre Yargitay Hukuk Genel Kurulu'nda tazminat dâvası açılabilmelidir. Esasen Yargıtay Başkan ve üyeleri aleyhine tazminat dâvasının açılabileceğini kabul edip, Danıştay Başkan ve üyeleri aleyhine açılamayacağını kabul etmek bu kişilere gereksiz bir imtiyaz tanımak olur ${ }^{77}$. Ayrica, davanın Hukuk Genel Kurulu'nda açılması, kuvvetler ayrıliğı ilkesine de aykırı değil$\operatorname{dir}^{78}$. Çünküi kuvvetler ayrılığı "devlet niteliğini kazanmış her siyasal toplumda, birbirinden farklı üç görev olduğu, bu görevlerden herbirini yerine getiren bir güç bulunduğu ve bunların birbirleri karşısında oldukça bağımsız bir statüye sahip oldukları esasına dayanır"79. Yani, yasama, yürütme ve yargı organlarının, Anayasa'nın başlangıç kısmında da belirtildiği gibi, birbirinden üstïnlüğü değil, aralarında, medenî bir işbölü̈mü ve işbirliği sözkonusudur. Danıştay Başkan ve üyeleri aleyhine Yargıtay Hukuk Genel Kurulu'nda dava açıldığında, yasama, yürütme ve yargının birbirlerine karşı olan bağımsızlıklan ve aralanındaki iş bölümü ilişkisi zedelenmez. Danıştay ve Yargıtay, her ikisi de yüksek yargı organıdır. Danıştay'ın görevinin, idarenin işlem ve eylemlerinin yargısal denetimi olması, onu yargı organı olmaktan çıkarmaz.

74. 4. HD 29.1.1959, 1386/963 (Son Içt. 1959/134, s.3899-3901).

75. RKD 1972/1, s.23-27.

76. RG 8.7.1964, S.11786, s.6.

77. Kunu IV s.3962; Bilge/Önen s.106-108; Belgesay-Şerh s.554; Kılıçoğlu s.240; Hallaç s.58; ayn yönde Ũstündağ s.112-113.

78. Bkz. yuk. dn.72.

79. Gözuibüyü̈k, A. Seref: Anayasa Hukuku, Ankara 1986, s.68. 